JURNAL PENA INDONESIA

Jurnal Bahasa Indonesia, Sastra, dan Pengajarannya

Volume 1, Nomor 2, Oktober 2015

ISSN: 22477-5150

\title{
STRUKTUR KONVERSASI WACANA DEBAT DALAM INDONESIA
}

\section{LAWYERS CLUB}

\author{
Dewi Puspa Arum \\ Pascasarjana, Universitas Negeri Surabaya \\ Email: puspanesia@gmail.com
}

\begin{abstract}
Abstrak
Konversasi dalam kaitannya dengan kajian pragmatik dapat dianalisis menggunakan berbagai teori. Salah satu teori yang digunakan dalam penelitian ini adalah pendekatan analisis percakapan yang selanjutnya dalam pembahasan ini disebut dengan analisis konversasi. Permasalahan tentang jeda, tumpang wicara, dan gilir wicara sering muncul dalam konversasi yang dilakukan dalam sebuah forum besar yang penuturnya banyak dan tidak ada kejelasan mengenai giliran bicara yang diberikan. Sehingga, dalam hal ini Indonesia Lawyers Club merupakan objek penelitian yang cocok untuk diteliti. Sesuai dengan fokus dan tujuan yang ada dalam penelitian ini, jenis penelitian ini adalah deskripitif kualitatif.Pemilihan jenis metode deskriptif dilakukan karena data tuturan dalam tayangan ILC memuat data-data yang dapat dikaji menggunakan teknik analisis konversasi dengan menggunakan penekanan pada tuturan yang menunjukan jeda, tumpang wicara, dan gilir wicara. Penguraian melalui deskripsi mendalam dan menyeluruh diharapkan mampu mencapai tujuan penelitian, yaitu mendeskripsikan dan menemukan jeda, tumpang wicara dan gilir wicara sampai menemukan prinsip strukturisasi wacana sesuai dengan data dan fokus masalah yang ada dalam penelitian ini. Pertama, jeda dalam ILC terbagi dapat dianalisis berdasarkan dua katagori, yang pertama berdasarkan durasi, dan yang kedua berdasarkan posisi. Kedua, gilir wicara dalam penelitian ini dapat dibagi menjadi dua katagori besar yaitu pasangan ujaran berdekatan dan mekanisme gilir wicara. Ketiga, tumpang wicara dalam penelitian ini dapat dibagi menjadi tiga katagori besar yaitu (1) tumpang kata, (2) tumpang frasa, dan (3) dan tumpang klausa. Tumpang kata dalam penelitian ini cenderung terjadi pada kondisi menyela. Tumpang Frasa dalam penelitian ini cenderung terjadi pada kondisi mencuri. Sementara itu, tumpang klausa dalam penelitian ini cenderung terjadi pada kondisi merebut.
\end{abstract}

Kata Kunci: struktur konversasi, jeda, gilir wicara, tumpang wicara

\begin{abstract}
Conversation in relation to pragmatic studies can be analyzed using a variety of theories. One theory used in this study is further conversation analysis approach in this discussion referred to the analysis of conversations. Issues of pause,
\end{abstract}


overlapping speech, and speech shifts often occur in conversations conducted in a large forum speakers lot and there is no clarity regarding the given speech turn. Thus, in this case Indonesia Lawyers Club is an ideal research object for study. In accordance with the focus and objectives described in this study, this kind of research is deskripitif kualitatif. First, a pause in the ILC is divided can be analyzed based on two categories, the first based on the duration, and the second based on the position. Second, the shift of speech in this study can be divided into two major categories, namely couples adjacent speech and speech-shift mechanism. Third, an overlap of speech in this study can be divided into three major categories: (1) overlap the word, (2) overlapping phrases, and (3) and overlapping clause. Overlapping word in this study tended to occur at interrupt condition. Overlapping phrase in this study tended to occur in conditions of stealing. Meanwhile, overlapping clause in this study tended to occur in conditions snatch.

Keywords: structure conversations, silence, turn taking, overlap

\section{PENDAHULUAN}

Konversasi merupakan tuturan dua arah yang melibatkan minimal dua orang untuk saling berinteraksi secara langsung. Dalam pelaksanaaannya, konversasi bukan hanya aktivitas pertuturan. Konversasi membutuhkan reaksi petutur baik itu melalui reaksi verbal maupun nonverbal yang mampu menunjukkan maksud dari tuturan yang akan disampaikan. Penelitian tentang konversasi berkaitan dengan ilmu kebahasaan. Hal itu karena bahasa digunakan sebagai media penyampai konversasi. Selain itu, konversasi dapat dianalisis menggunakan ilmu kebahasaan yaitu dengan kajian pragmatik.

Dalam kaitannya dengan kajian pragmatik, konversasi dapat dianalisis menggunakan berbagai teori. Salah satu teori yang digunakan dalam penelitian ini adalah pendekatan analisis percakapan yang selanjutnya dalam pembahasan itu disebut dengan analisis konversasi. Pendekatan analisis konversasi merupakan pendekatan yang digunakan dalam cabang ilmu pragmatik untuk menganalisis struktur konversasi. Analisis struktur konversasi melibatkan beberapa kajian untuk dianalisis di antaranya yaitu jeda, overlap, dan turn taking. Dalam penelitian itu, istilah jeda tetap digunakan, sementara istilah overlap selanjutnya akan disebut 
sebagai tumpang wicara dan turn taking akan disebut sebagai gilir wicara. Penelitian tentang konversasi ternyata juga berkaitan dengan ilmu sosiologi. Seperti yang diungkapkan oleh ahli sosiologi dapat dilakukan melalui kajian sosiologi seperti Harvey Sacks, Gail Jefferson, dan Emanuelh Schegloff (1960) yang memunculkan "analisis konversasi" dalam bidang sosiologi untuk mengaji struktur dan organisasi teks konversasi.

Struktur konversasi penting untuk dikaji karena dalam konversasi ditemukan hal penting yang dapat membuat konversasi menjadi lebih mudah dipahami dan menunjukkan bagaimana bahasa bekerja dalam konversasi yaitu tentang struktur bahasa dan pemakaian bahasa seperti yang diungkapkan oleh Firth (dalam Coulthard 1978:1). Namun, ada satu masalah yang muncul yakni dalam mendistribusikan struktur bahasa tersebut dalam pemakaian bahasa khususnya konversasi. Oleh karena itu, analisis tentang struktur bahasa tidak dapat dipisahkan dengan konversasi.

Mey (2001: 137) berpendapat bahwa konversasi, sebagai wujud penggunaan bahasa untuk berinteraksi, dapat dilihat dari dua aspek. Aspek pertama adalah isi (content), yaitu aspek yang memperhatikan halhal seperti topik apa yang didiskusikan dalam konversasi; bagaimana topik disampaikan dalam konversasi: apakah secara eksplisit, melalui presuposisi, atau diimplisitkan dengan berbagai macam cara; jenis topik apa yang mengarah pada topik lain dan apa alasan yang melatarbelakangi hal semacam itu terjadi, dsb. Selain itu, fokus lain dari aspek itu adalah organisasi topik dalam konversasi dan bagaimana topik dikelola, apakah disampaikan dengan cara terbuka atau dengan manipulasi secara tertutup: biasanya dalam bentuk tindak ujar tak langsung. Kedua adalah aspek formal konversasi. Fokus utama dalam aspek itu adalah hal-hal seperti bagaimana konversasi bekerja; aturan-aturan apa yang dipatuhi; dan bagaimana sequencing 
'keberuntutan' dapat dicapai (memberikan dan memperoleh giliran atau mekanisme gilir wicara, jeda, interupsi, tumpang wicara, dan lain-lain).

Dalam sebuah konversasi, para partisipan seolah-olah mengetahui dan menaati suatu aturan sehingga dapat saling berbagi peran: siapa yang mendapatkan giliran berbicara, siapa yang mendapatkan giliran mendengarkan, lalu mereka saling berganti peran sehingga konversasi dapat berjalan lancar. Seperti pendapat Cutler dan Pearson (dalam Sabat 1991: 161) yang menyatakan bahwa, agar konversasi berjalan dengan sukses, ada beberapa aturan yang perlu diperhatikan, yaitu penutur hendaknya tidak menguasai giliran berbicara terlalu lama dan seharusnya ujaran yang dituturkannya dapat diselesaikan tanpa adanya interupsi, dan di akhir giliran bicaranya, penutur lain harus mengambil alih giliran tanpa diawali dengan jeda yang terlalu lama.

Dalam kamus linguistik struktur adalah perangkat unsur yang di antaranya ada hubungan yang bersifat ekstrinsik yaitu unsur dan hubungan itu bersifat abstrak dan bebas dari isi yang bersifat intuitif, sedangkan konversasi adalah suatu interaksi bahasa antara dua pembicara atau lebih (Kridalaksana, 1983:130).

Jeda merupakan pertukaran bicara dari setiap penutur yang diberikan pada penutur selanjutnya untuk berbicara. Pertukaran bicara dapat berupa dua kondisi yakni pertukaran disertai dengan kesenyapan yang lama atau adanya tumpang wicara. Apabila pertukaran yang disertai dengan kesenyapan yang lama diantara dua giliran, maka dirasakan konversasi yang terjadi terasa kaku. Jeda yang sangat pendek merupakan bentuk keragu-raguan, sedangkan jeda yang panjang menjadi kesenyapan (Yule, 1996: 125).

Gilir wicara merupakan pergantian peran penutur dalam konversasi. Pergantian peran penutur dalam konversasi sangat erat kaitannya dengan budaya suatu komunitas tutur. Hal itu disebabkan karena setiap bahasa dan 
budaya memiliki konvensi, strategi, dan perangkat tertentu untuk mengatur interaksi dalam konversasi (Kachru \& Smith, 2008).

Tumpang wicara yaitu penutur selanjutnya memprediksi bahwa penutur sebelumnya akan segera memberikan giliran berbicara kepada penutur selanjutnya, maka ia mengambil alih giliran berbicara. Tumpang wicara juga dapat ditandai dengan kedua penutur yang mencoba untuk berbicara pada saat yang sama (Yule, 1996: 124). Meskipun, tumpang wicara bukanlah sesuatu hal yang terlihat tidak wajar dalam konversasi alamiah, terdapat fakta yang cukup mengejutkan bahwa tidak lebih dari lima persen tumpang wicara muncul dalam konversasi alamiah dan jeda antarpartisipan bergiliran berbicara hanya beberapa "mikro-detik" (Levinson, 1983: 296).

Permasalahan tentang jeda, tumpang wicara, dan gilir wicara sering muncul dalam konversasi yang dilakukan dalam sebuah forum besar yang penuturnya banyak dan tidak ada kejelasan mengenai giliran bicara yang diberikan. Sehingga, Indonesia Lawyers Club merupakan objek penelitian yang cocok untuk diteliti. Indonesia Lawyers Club merupakan acara perkumpulan pengacara-pengacara Indonesia yang ditayangkan oleh stasiun televisi TV-One setiap hari Selasa pukul 20.00-22.00. Indonesia Lawyers Club untuk selanjutnya disingkat menjadi ILC.

ILC merupakan acara diskusi yang tidak hanya dihadiri oleh pengacarapengacara saja, tetapi juga dihadiri oleh mahasiswa dan politikus. ILC merupakan acara yang membahas isu-isu yang masih hangat dan sedang berkembang di masyarakat. Pembahasan mengenai isu-isu tersebut dipimpin oleh Karni Ilyas selaku moderator yang akan menggiring jalannya diskusi dengan beberapa pertanyaan terkait isu-isu tersebut. Pertanyaan-pertanyaan Karni llyas itulah yang akan dilempar kepada peserta untuk dimintai pendapat. Dalam meminta pendapat, biasanya Karni Ilyas akan meminta pendapat salah satu peserta yang hadir, lalu pendapat tersebut boleh dikomentari oleh peserta yang lain. Pro dan kontra selalu muncul dalam pendapat peserta yang hadir. Hal itulah yang membuat ILC menyuguhkan banyak 
wacana debat di dalamnya. Sementara itu, tidak adanya pembagian gilir wicara yang jelas untuk para peserta yang akan menyampaikan pendapatnya, maka sering muncul masalah jeda dan tumpang wicara. Oleh karena itu, ILC merupakan wacana debat yang cocok untuk dijadikan objek kajian dalam penelitian ini.

\section{METODE}

Sesuai dengan fokus dan tujuan, jenis penelitian ini adalah deskripitif kualitatif. Penelitian tersebut dilakukan dengan mendeskripsikan data berupa tuturan-tuturan yang menunjukkan adanya jeda, tumpang wicara, dan gilir wicara. Tuturan-tuturan tersebut dideskripsikan untuk menjawab fokus penelitian, kemudian dianalisis untuk mencapai tujuan penelitian.

Pemilihan jenis metode deskriptif dilakukan karena data tuturan dalam tayangan ILC memuat data-data yang dapat dikaji menggunakan teknik analisis konversasi dengan menggunakan penekanan pada tuturan yang menunjukkan jeda, tumpang wicara, dan gilir wicara. Penguraian melalui deskripsi mendalam dan menyeluruh diharapkan mampu mencapai tujuan penelitian, yaitu mendeskripsikan dan menemukan jeda, tumpang wicara dan gilir wicara sampai menemukan prinsip strukturisasi wacana sesuai dengan daata dan fokus masalah yang ada dalam penelitian ini.

Metode penelitian ini dipilih berdasarkan pendapat Lincon dan Guba dalam Moleong (2002:6-7), yaitu karena (1) data yang dikumpulkan berupa kata-kata atau kalimat bukan angka-angka; (2) analisis data bukan dimaksudkan untuk membuktikan kebenaran hipotesis; (3) adanya batas yang ditentukan oleh fokus permasalahan.

Dalam penelitian ini, dideskripsikan fenomena-fenomena penggunaan bahasa yang muncul dalam percakapan dan perdebatan dalam Indonesia Lawyers Club. Fenomena yang menjadi fokus dalam penelitian ini adalah struktur konversasi yang berkaitan dengan jeda, tumpang wicara dan gilir wicara. 
Sumber data pada penelitian ini adalah tayangan ILC sesuai dengan kriteria yang telah ditentukan sebelumnya. Data dalam penelitian ini adalah tuturantuturan semua peserta dalam ILC yang memiliki kriteria sesuai dengan yang dibutuhkan dalam penelitian. Kriteria tersebut antara lain: (1) jenis topik yang dibahas adalah kasus-kasus nasional; (2) jenis topik yang dibahas dibatasi pada topik yang sama yaitu mengenai korupsi; (3) jenis topik yang dibahas yaitu topik yang di dalamnya banyak ditemukan wacana debat yang ditandai dengan ditemukannya ujaran yang saling memotong, menyela, dan bergiliran.

Dalam penelitian ini, pengumpulan data menggunakan metode dokumentasi. Metode dokumentasi dilakukan dengan mengunduh tayangan ILC sesuai dengan kriteria yang telah ditentukan. Berdasarkan metode dokumentasi, teknik yang digunakan dalam pengumpulan data adalah teknik pilih langsung. Teknik itu dilakukan dengan cara sebagai berikut: 1) mengunduh video hasil rekaman tayangan ILC yang ada di youtube, 2) mengklasifikasi video yang diunduh berdasarkan kelompok topik dan masalah sesuai dengan kriteria yang ditentukan, 3) mentranskripsi tuturan yang ada dalam ILC sesuai dengan kriteria yang telah ditentukan, dan 4) menentukan data yang memenuhi syarat dan tidak memenuhi syarat sesuai dengan batasan yang telah dibuat sebelumnya.

Peneliti merupakan intrumen utama dalam penelitian. Peneliti berperan sebagai pengumpul data dengan cara mentranskrip dan mengklasifikasi tuturantuturan yang ada dalam ILC sesuai dengan kriteria yang telah ditentukan dalam penelitian tersebut.

Metode analisis data yang digunakan dalam penelitian ini adalah metode deskriptif. Berkaitan dengan analisis deskriptif, Sunarto (2001:157) menjelaskan bahwa analisis deskriptif diawali dengan pengkategorian data menurut aspek dan subaspek serta menjelaskan hubungan aspek yang satu dengan aspek yang lain. Selanjutnya, dilakukan analisis dan interpretasi secara utuh dan menyeluruh mengarah ke fokus permasalahan yang dilakukan secara induktif. 
Metode deskriptif yang digunakan dalam penelitian ini khususnya menggunakan metode padan untuk penyajian dan pengajian data. Metode padan yang digunakan meliputi metode padan dengan alat penentu pragmatis dan alat teknik pilah unsur penentu. Selain itu, juga digunakan pula metode agih dengan alat penentu permutasi. Alat penentu permutasi digunakan untuk menganalisis efek dari penggunaan jeda panjang dan jeda pendek, maupun posisi jeda dalam kalimat.

Penyajian dan pengajian data menggunakan metode padan dengan alat penentu pragmatis dan menggunakan teknik pilah unsur penentu. Alat penentu pragmatis digunakan untuk menganalisis mekanisme gilir wicara dan pasangan ujaran berdekatan, serta adanya tumpang wicara yang muncul dalam percakapan penutur dan petutur. Teknik pilah unsur penentu yang digunakan dalam penelitian itu adalah daya pilah sebagai pembeda reaksi dan kadar keterdengaran yang digunakan untuk menentukan reaksi petutur dengan adanya tuturan yang disampaikan oleh penutur dan kadar keterdengaran yang dapat menunjukkan jenis kalimat berdasarkan tanda baca intonasi final.

Dalam menganalisis data dilakukan berberapa proses yang terdiri atas menginterpretasi, mengidentifikasi masalah, mendiskusikan masalah, dan mengemukakan opini berkaitan dengan data yang dibahas. Keempat hal tersebut terangkum dalam proses deskripsi, interpretasi, dan eksplanasi. Deskripsi dilakukan untuk mengurai data hingga mencapai kedalaman yang diinginkan. Interpretasi dilakukan untuk memaknai fakta yang ditemukan. Eksplanasi dilakukan utuk menjelaskan efek dari penggunaan jeda panjang dan pendek, untuk menjelaskan pasangan ujaran berdekatan dan mekanisme gilir wicara, serta bentuk-bentuk pertumpangan dalam tumpang wicara wacana debat ILC yang menjadi fokus penelitian. Eksplanasi juga mengantarkan peneliti pada penyimpulan sesuai dengan fokus penelitian, yaitu jeda, tumpang wicara, dan gilir wicara. 


\section{HASIL DAN PEMBAHASAN}

Berdasarkan rumusan masalah, ada tiga hal yang dibahas dalam penelitian ini, yaitu (1) jeda dalam wacana debat ILC, (2) gilir wicara dalam wacana debat ILC, dan (3) tumpang wicara dalam wacana debat ILC

\section{Jeda dalam Wacana Debat ILC}

Dalam bab ini dipaparkan hasil penelitian yang mencakup penyajian dan pengajian dari fokus permasalahan pertama yang ada dalam penelitian "Struktur Wacana Debat dalam Indonesia Lawyers Club. Fokus permasalahan pertama tentang jeda dalam wacana debat ILC, terdiri atas (1) jeda berdasarkan durasi waktunya, (2) jeda berdasarkan letaknya dalam kalimat. Penyajian dan pengajian data menggunakan metode padan dengan alat penentu pragmatis dan alat penentu ortografis, serta metode agih dengan alat penentu permutasi. Alat penentu pragmatis digunakan untuk menganalisis gilir wicara dan tumpang wicara yang timbul dalam percakapan. Alat penentu ortografis digunakan untuk menganalisis perbedaan jeda dalam segi tulisan dan pengucapan yang dikaitkan dengan teori struktur percakapan. Alat penentu permutasi digunakan untuk menganalisis efek dari penggunaan jeda panjang dan jeda pendek, mau emansipasi $\operatorname{sisi}_{\text {jadi }}$ jeda dalam kalimat. Jeda dalam penelitian ini dapat dibedakan berdasarkan dua hal, yaitu jeda berdasarkan durasi waktunya dan jeda berdasarkan letaknya dalam kalimat.

Jeda dalam wacana debat ILC dapat dibedakan menjadi dua jenis berdasarkan lamanya waktu yang digunakan, yaitu (1) jeda pendek, (2) jeda panjang, dan (3) Jeda Selaan. Durasi waktu untuk menentukan lamanya waktu yang muncul dari penggunaan jeda panjang, pendek, dan selaan belum ditemukan secara pasti dalam satuan detik. Oleh karena itu, dalam penelitian ini, pembagian jeda pendek, panjang, dan selaan ditentukan berdasarkan lamanya waktu yang muncul di sekitar tuturan sehingga memiliki potensi kecenderungan 
untuk disela ataupun tidak disela. Untuk hitungan detik dalam hal durasi panjang dan pendek jeda yang digunakan, dalam penelitian ini dapat ditunjukkan dengan analisis menggunakan bantuan program PRAAT. Sehingga, pada akhirnya dapat diambil simpulan mengenai rentang waktu yang muncul pada masingmasing jenis jeda.

Jeda pendek dalam penelitian ini adalah tuturan yang memiliki jeda dengan durasi waktu yang tidak memiliki kemungkinan untuk disela. Sementara itu, jeda panjang dalam penelitian ini adalah tuturan yang memiliki jeda dengan durasi waktu yang memiliki kemungkinan untuk disela. Jeda selaan dalam penelitian ini dideskripsikan sebagai kondisi tanpa jeda dalam suatu tuturan yang terjadi akibat adanya tumpang wicara.

Berikut adalah contoh konversasi yang jeda berdasarkan durasi dalam wacana debat ILC.

001 Apa ini gara-gara emansipasi?/ Jadi ada perempuan

$a \quad b$

banyak jadi DPR/ kemudian jadi gubernur jadi menteri/ jadi pengacara politisi/

(0001/Je-Pd/Kar/K1)

Data 001 merupakan tuturan yang terjadi pada awal acara Indonesia Lawyers Club dimulai. Kar sebagai moderator dalam acara debat tersebut bertanya pada Suj selaku seniman pengisi acara mengenai $a$. Kemudian, kalimat dalam tuturan tersebut dilanjutkan dengan kalimat selanjutnya yang ditandai dengan $b$. Jeda dalam tuturan tersebut berada diantara dua kalimat dalam satu tuturan. Durasi jeda tersebut terdapat dalam data gelombang suara program PRAAT berikut ini. 


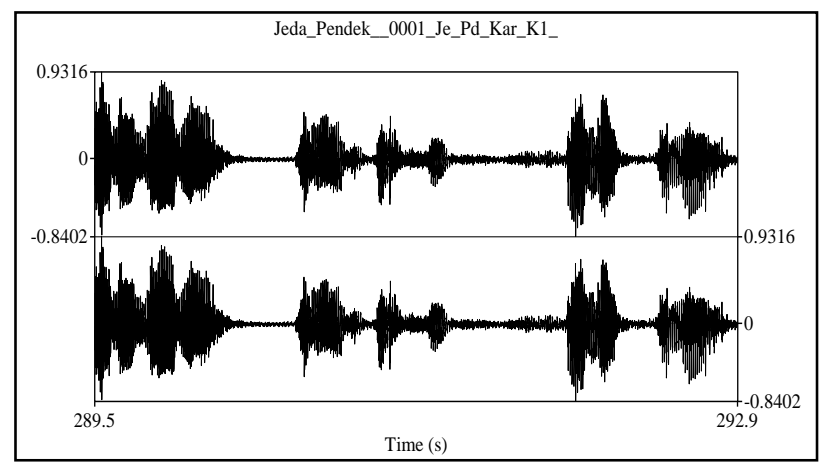

Secara tematik, data 001 dalam kalimat pertama memberikan penekanan makna pada a yaitu pada kata emansipasi, yang bermakna persamaan hak di berbagai aspek kehidupan masyarakat. Efek jeda pendek dalam tuturan ini membuat penonton berfokus pada $a$, yang merupakan awal dari sebuah simpulan yang disampaikan dalam kalimat selanjutnya yang ditandai dengan $b$ yaitu kata jadi. Kalimat kedua, yang diawali dengan $b$, merupakan sebuah kalimat simpulan yang memperkuat pernyataan sebelumnya bahwa $a$ menyebabkan perempuan memiliki hak yang sama dengan laki-laki dalam hal pekerjaan. Munculnya jeda pendek di antara kedua kalimat tersebut memiliki fungsi sebagai pemisah antara kalimat pertama dan kalimat kedua. Selain itu, jeda pendek tersebut memiliki efek sebagai penghubung antara kata $a$ dan $b$ agar memiliki satu keterkaitan yaitu sebab-akibat.

\section{Gilir Wicara}

Fokus selanjutnya, yaitu tentang gilir wicara dalam wacana debat ILC, terdiri atas (1) pasangan ujaran berdekatan dan (2) mekanisme giliran bicara yang terdiri atas 3 aturan yaitu aturan apa yang berlaku untuk mendapatkan giliran bicara, aturan apa yang berlaku untuk memberikan giliran bicara, dan aturan apa yang berlaku untuk menguasai pembicaraan.

Pasangan ujaran berdekatan merupakan salah satu pola alih tutur pasangan ujaran berdekatan merupakan cara untuk menentukan penutur berikutnya. 
Dalam proses konversasi pasangan berdekatan itu memberikan kerangka untuk melakukan interpretasi. Pola peralihan tutur yang menggunakan pasangan ujaran berdekatan itu banyak digunakan oleh pada peserta konversasi. Pasangan ujaran berdekatan yang ada dalam penelitian ini dibagi dalam beberapa jenis seperti dalam data berikut ini.

002 Kar: a. Saya terpaksa mengundang saudara saya/ Johan Budi sebagai juru bicara KPK\#// Malam-malam biasanya sore-sore/ Anda yang pertama sore biasanya/tapi sekarang/ malam-malam/

b. Johan Budi lagi yang pertama/ Kemarin sore kalau saya gak salah monitor dari KPK/ bahwa/ sprindik terhadap si ... apa namanya ... Gubernur Atut belum ada\#/ baru akan dirapatkan sore tadi/ Tibatiba/ mengagetkan saya juga!/

c. Rumahnya tadi pagi digeledah/ udah ada juga sprindiknya/ kemudian juga/ siang resmi menjadi tersangka/ apa yang terjadi dalam kurun waktu nggak sampe 12 jam atau 24 jam?/

Joh : d. [Gw] Ya terima kasih Bang Karni/

e. Jadi/ tentu bukan tiba-tiba ya/ kemudian KPK menetapkan/ Gubernur Banten sebagai tersangka dalam kaitan dengan kasus dugaan tindak pidana korupsi/ dalam kaitan dengan pengurusan sengketa pilkada Kabupaten Lebak di Mahkamah Konstitusi/

f. Pekan lalu sebenarnya ada gelar perkara ya $\mathbf{F}$

(003/GW/K1/T-02/ Sil-Ter/Get-Olh

Pada data 002, Kar selaku $n$ memberikan pertanyaan kepada Joh selaku $t$ tentang $c$. Pertanyaan tersebut ditandai dengan penggunaan kata tanya apa yang terjadi. Lalu, Joh menjawab pertanyaan Kar dengan pernyataan yang berupa jawaban pembenaran atas pertanyaan yang diajukan seperti dalam $e$. Jawaban tersebut ditandai dengan penggunaan bagian jadi tentu bukan tiba-tiba ya yang di dalamnya menunjukkan maksud bahwa KPK tidak memberikan status tersangka pada Gubernur Banten secara tiba-tiba. Dalam penggalan konversasi tersebut, bagian pertama yang disampaikan Kar merupakan pernyataan panjang yang memiliki tiga pola kalimat, yaitu kalimat menyilakan seperti yang terdapat dalam $a$, kalimat pernyataan seperti yang terdapat dalam $b$, dan kalimat pertanyaan yang terdapat dalam c. Bagian pertama tersebut berpasangan 
dengan bagian kedua yang memiliki tiga pola kalimat juga, yaitu kalimat ucapan terima kasih seperti yang terdapat dalam $d$ dan kalimat jawaban seperti yang terdapat dalam $e$ dan $f$.

Untuk menentukan apakah bagian pertama dan bagian kedua tersebut merupakan pasangan ujaran berdekatan dengan pola pertanyaan jawaban, maka digunakan pengujian dengan teknik pilah unsur penentu untuk menentukan daya pilah sebagai pembeda reaksi dan kadar keterdengaran yang digunakan untuk menentukan reaksi $t$ dengan adanya tuturan yang disampaikan oleh $n$ dan kadar keterdengaran yang dapat menunjukkan jenis kalimat berdasarkan tanda baca intonasi final. Pengujian tersebut tampak dalam data berikut ini.

002a. Kar: a. Saya terpaksa mengundang saudara saya/ Johan Budi sebagai juru bicara KPK\#/ ...

Joh : c. [Gt] Ya terima kasih Bang Karni\#/

Pada data 002a, $b$ dalam bagian pertama data tersebut dihilangkan. Demikian pula dengan $d$ pada bagian kedua juga dihilangkan. Data 002a menunjukan adanya tuturan $a$ yang merupakan tuturan dengan pola kalimat menyilakan $t$ untuk menjadi pembicara dalam acara debat tersebut. Hal ini ditunjukkan dengan kata mengundang Johan Budi sebagai juru bicara KPK. Pada kalimat $a, n$ menggunakan kata mengundang untuk menyilakan $t$ memberikan pendapat atas topik yang sedang dibahas dalam debat tersebut.

Sementara itu, pada 'bagian kedua, $t$ menggunakan tuturan kalimat $c$ untuk merespon tuturan kalimat $a$ yang disampaikan $t$. Tuturan dalam kalimat $c$ berisi kalimat yang menyatakan ucapan terima kasih atas kesempatan yang telah diberikan oleh $n$ untuk memberikan tanggapan terkait topik yang sedang dibahas dalam debat tersebut. Hal ini ditandai dengan penggunaan kata terima kasih Bang Karni yang sebelumnya didahului dengan penggunaan back channel berupa kata ya. Tuturan a merupakan ungkapan yang berisi pernyataan 
menyilakan dan memberikan kesempatan berbicara pada $t$, sedangkan tuturan $c$ merupakan tuturan yang berisi ungkapan penerimaan dan ucapan terima kasih kepada $t$ atas kesempatan berbicara yang telah diberikan. Data 002a berisi pasangan ujaran berdekatan berpola menyilakan-berterima kasih, sehingga dalam data 018a tidak terdapat pasangan ujaran berdekatan dengan pola pertanyaan-jawaban. Oleh karena itu, data 002 perlu diuji kembali dengan pola yang berbeda.

002b. Kar: b. Rumahnya tadi pagi digeledah/ udah ada juga sprindiknya/kemudian juga/ siang resmi menjadi tersangka/ apa yang terjadi dalam kurun waktu nggak sampe 12 jam atau

\section{4 jam?}

Joh : d. Jadi/ tentu bukan tiba-tiba ya/ kemudian KPK menetapkan/ Gubernur Banten sebagai

Pada data 002b, a dalam bagian pertama data tersebut dihilangkan. Demikian pula dengan $c$ pada bagian kedua juga dihilangkan. Data 002b menunjukan adanya tuturan $b$ yang merupakan tuturan dengan pola kalimat menanyakan sesuatu dalam acara debat tersebut. Hal ini ditunjukkan dengan kata apa yang terjadi dalam kurun waktu nggak sampai 12 jam atau 24 jam?. Pada kalimat $b, n$ menggunakan kata tanya apa yang terjadi untuk menanyakan pada $t$ mengenai peristiwa apa yang terjadi sehingga KPK dapat secara cepat menetapkan status tersangka pada Gubernur Banten seperti yang dibahas dalam topik debat tersebut. Tuturan a merupakan tuturan yang berupa kalimat tanya yang sebelumnya diawali dengan kalimat kalimat-kalimat pengantar yang memberikan gambaran atas pertanyaan yang akan diajukan oleh $t$ hingga pada akhirnya $t$ menyampaikan pertanyaan di akhir tuturan.

Sementara itu, pada `bagian kedua, $t$ menggunakan tuturan kalimat $d$ untuk merespon tuturan kalimat $b$ yang disampaikan $t$. Tuturan dalam kalimat $d$ berisi kalimat yang berisi jawaban atas pertanyaan yang telah diberikan oleh $n$ terkait 202 | ISSN: 22477-5150 http://journal.unesa.ac.id/index.php/jpi 
topik yang sedang dibahas dalam debat tersebut. Hal ini ditandai dengan penggunaan kata tentu bukan tiba-tiba ya yang sebelumnya didahului dengan penggunaan back channel berupa kata jadi. Penggunaan kata tentu bukan tibatiba ya merupakan penunjuk untuk menjawab pertanyaan $t$ seperti dalam $b$ yang menanyakan mengapa KPK dapat dengan cepat menentukan status Gubernur Banten menjadi tersangka. Tuturan $b$ merupakan tuturan yang berisi pertanyaan pada $t$, sedangkan tuturan $d$ merupakan tuturan yang berisi jawaban atas pertanyaan yang diajukan $n$. Data $002 \mathrm{~b}$ berisi pasangan ujaran berdekatan berpola pertanyaan-jawaban, sehingga dalam data 002b terdapat pasangan ujaran berdekatan dengan pola pertanyaan-jawaban.

Dengan demikian, dapat disimpulkan bahwa dalam data 002, yang menyebabkan data tersebut memiliki pola ujaran terdekat pertanyaan-jawaban adalah tuturan $a$ dan tuturan $c$. Sementara itu, tuturan $a$ dan tuturan $c$ yang muncul dalam data 002 tersebut dapat digolongkan sebagai pelengkap tuturan dalam pasangan ujaran berdekatan yang letaknya diawal tuturan $n$ dan tuturan $t$.

\section{Tumpang Wicara}

Fokus selanjutnya tentang tumpang wicara dalam wacana debat ILC, yang terdiri atas (1) tumpang kata, (2) tumpang frasa, dan (3) tumpang klausa. Pada tumpang frasa, tumpang kata, dan tumpang klausa tersebut, tiap-tiap tumpang wicara tersebut dibagi menjadi tiga katagori yaitu menyela, mencuri, dan merebut. Pembahasan berikut ini akan mengklasifikasikan kombinasi antara jenis tumpang wicara dan kondisi pada tiap-tiap jenis.

Tumpang kata merupakan kondisi tumpang wicara yang terjadi akibat adanya tuturan bersamaan yang diujarkan oleh $n$ dan $t$. Ciri utama adanya tumpang kata adalah tuturan bersamaan pada 1-2 kata terakhir tuturan $n$ yang diujarkan bersamaan dengan 1-2 kata di awal tuturan $t$. Selain itu, ciri lain adanya 
tumpang kata yaitu durasi terjadinya tumpang wicara yang singkat karena hanya terjadi pada 1-2 kata.

Ciri lainnya yaitu tumpang kata mendominasi tumpang wicara pada jenis menyela. Hal ini dikarenakan tumpang wicara pada jenis menyela umumnya terjadi ketika $t$ sudah memperkirakan bahwa $n$ akan mengakhiri tuturannya.selain itu, keadaan menyela dapat pula terjadi akibat adanya kesepahaman $t$ terhadap apa yang sedang dituturkan oleh $n$ sehingga menyatakan persetujuannya saat $n$ sedang menyampaikan tuturan dan tidak menyebabkan $n$ menghentikan tuturannya. Namun, selain didominasi oleh jenis menyela, ditemukan pula tumpang kata untuk jenis mencuri dan merebut seperti yang disajikan dalam pembahasan berikut ini. Tumpang kata jenis menyela merupakan jenis tumpang wicara yang terjadi pada akhir tuturan $n$ dan awal tuturan $t$. Tumpang kata jenis menyela ini merupakan jenis tumpang kata yang paling sering ditemukan dalam penelitian ini.

Tumpang frasa merupakan kondisi tumpang wicara yang terjadi akibat adanya tuturan bersamaan yang diujarkan oleh $n$ dan $t$. Ciri utama adanya tumpang frasa adalah tuturan bersamaan pada 3-4 kata terakhir tuturan $n$ yang diujarkan bersamaan dengan 3-4 kata di awal tuturan $t$. Selain itu, ciri lain adanya tumpang frasa yaitu durasi terjadinya tumpang wicara yang lebih panjang dari tumpang kata karena terjadi pada 3-4 kata. Selain itu, ciri lainnya yang dapat diamati yaitu pada saat terjadi tumpang wicara, jenis tuturan ini tidak memiliki tuturan panjang setelah bagian yang dituturkan bersamaan oleh $t$ dan $n$.

Ciri lainnya yaitu tumpang frasa mendominasi tumpang wicara pada jenis mencuri. Hal ini dikarenakan tumpang wicara pada jenis mencuri umumnya terjadi dengan fungsi untuk mengklarifikasi pertanyaan $n$ yang kurang tepat, untuk mengklarifikasi pernyataan $t$ atas pertanyaan yang diajukan $n$ sebelumnya, dan untuk menyatakan pernyataan kontra atas pernyataan dan pertanyaan sebelumnya. Namun, selain didominasi oleh jenis mencuri, ditemukan pula tumpang frasa untuk jenis menyela. 
Tumpang klausa merupakan kondisi tumpang wicara yang terjadi akibat adanya tuturan bersamaan yang diujarkan oleh $n$ dan $t$. Ciri utama adanya tumpang klausa adalah tuturan bersamaan pada lebih dari 4 kata terakhir tuturan $n$ yang diujarkan bersamaan dengan lebih dari 4 kata di awal tuturan $t$. Selain itu, ciri lain adanya tumpang klausa yaitu durasi terjadinya tumpang wicara yang lebih panjang dari tumpang frasa karena terjadi pada lebih dari 4 kata. Selain itu, ciri lainnya yang dapat diamati yaitu pada saat terjadi tumpang wicara, jenis tuturan ini masih memiliki tuturan selanjutnya setelah bagian yang dituturkan bersamaan oleh $t$ dan $n$. Oleh karena itu, tampak dalam tuturan tersebut, $t$ merebut giliran wicara $n$ dan $t$ melanjutkan dengan pernyataanpernyataan yang lebih panjang.

Ciri lainnya yaitu tumpang klausa mendominasi tumpang wicara pada jenis merebut. Hal ini dikarenakan tumpang wicara pada jenis merebut umumnya terjadi karena (1) $n$ sedang lengah dan belum menemukan kata-kata yang tepat untuk melanjutkan tuturan yang ditandai dengan munculnya tanda titik tiga kali (...), (2) karena uraian yang disampaikan oleh $n$ tidak sesuai dengan jawaban yang diharapkan oleh $t$, (3) karena $t$ merasa perlu untuk mengklarifikasi uraian yang disampaikan $n$ dan untuk memberikan pertanyaan lanjutan agar uraian $n$ lebih terarah sesuai dengan harapan $t$, (4) karena kesalahan perkiraan $t$ bahwa dirinya telah dipersilahkan oleh $n$ setelah muncul kata persilahkan, padahal $n$ belum selesai menggunakan gilir wicaranya, (5) karena adanya pernyataan kesepahaman yang berupa sindiran terhadap apa yang disampaikan oleh $n,(6)$ karena jawaban $n$ belum sesuai harapan $t,(7)$ sehingga $t$ mengarahkan pernyataan $n$ dengan memberikan pertanyaan lanjutan, (8) dan karena $n$ ingin menyatakan pertanyaan lanjutan atas jawaban yang sedang disampaikan oleh $t$. Namun, selain didominasi oleh jenis merebut, ditemukan pula tumpang klausa untuk jenis menyela dan mencuri seperti yang disajikan dalam pembahasan berikut ini. 
Tumpang klausa jenis menyela merupakan jenis tumpang wicara yang tidak ditemukan dalam data wacana debat ILC. Hal ini dikarenakan tumpang klausa merupakan tumpang wicara yang di dalamnya terdapat pertumpangan lebih dari empat kata di dalamnya. Hal ini tidak sesuai dengan konsep menyela yang di dalamnya terdapat pertumpangan 1-2 kata secara bersamaan. Dengan demikian, tumpang klausa jenis menyela tidak dapat ditemukan dalam data penelitian wacana debat ILC. Meskipun tidak ditemukan tumpang klausa jenis menyela, namun dalam penelitian ini dapat ditemukan tumpang klausa jenis mencuri seperti data berikut ini.

Data 003 merupakan bagian dari acara debat ILC Korupsi 2. Pada data tersebut, $n$ menanyakan apakah saksi yang dipanggil oleh KPK mengaku seperti pada a. Hal ini ditandai dengan bagian Sutan Batugana mengaku nggak/ waktu di periksa? Kemudian, $t$ menjawab seperti pada $b$. Secara bersamaan, pada bagian $b$ terjadi tumpang wicara dengan bagian $c$. Tumpang wicara yang terjadi yaitu pada klausa =dan saya tidak tau Pak Sutan ini ditanya apa? seperti dalam $b$, dan ya nanti kan datanya kan saya tanya juga= seperti dalam $c$.

Tumpang wicara yang terjadi pada data 041 merupakan jenis tumpang wicara yang terjadi pada $>4$ kata sehingga disebut sebagai tumpang klausa. Selain itu, data 040 digolongkan dalam tumpang frasa jenis mencuri karena bagian yang saling bertumpangan merupakan klausa yang tidak dilanjutkan dengan kalimat panjang berupa tuturan eksplanasi. Sehingga, dalam klausa $b$ dan $c$, baik $n$ maupun $t$ menjelaskan hal yang sama. Kesamaan hal yang dibahas adalah pada pembahasan mengenai masalah pertanyaan apa yang diberikan pada saksi dalam hal ini adalah Sutan Batoegana.

Pada klausa tidak ditemukan data tuturan tumpang klausa jenis menyela. Hal ini dikarenakan klausa merupakan tumpang wicara yang di dalamnya terdapat pertumpangan lebih dari empat kata di dalamnya. Hal ini tidak sesuai dengan konsep menyela yang di dalamnya terdapat pertumpangan 1-2 kata secara bersamaan. Dengan demikian, tumpang klausa jenis menyela 206 | ISSN: 22477-5150 http://journal.unesa.ac.id/index.php/jpi 
tidak dapat ditemukan dalam data penelitian wacana debat ILC. Sementara itu, ditemukan 11 data tumpang klausa jenis mencuri dan 13 sata tumpang klausa jenis merebut. Oleh karena itu, tumpang klausa merupakan jenis tumpang wicara yang didominasi oleh jenis merebut.

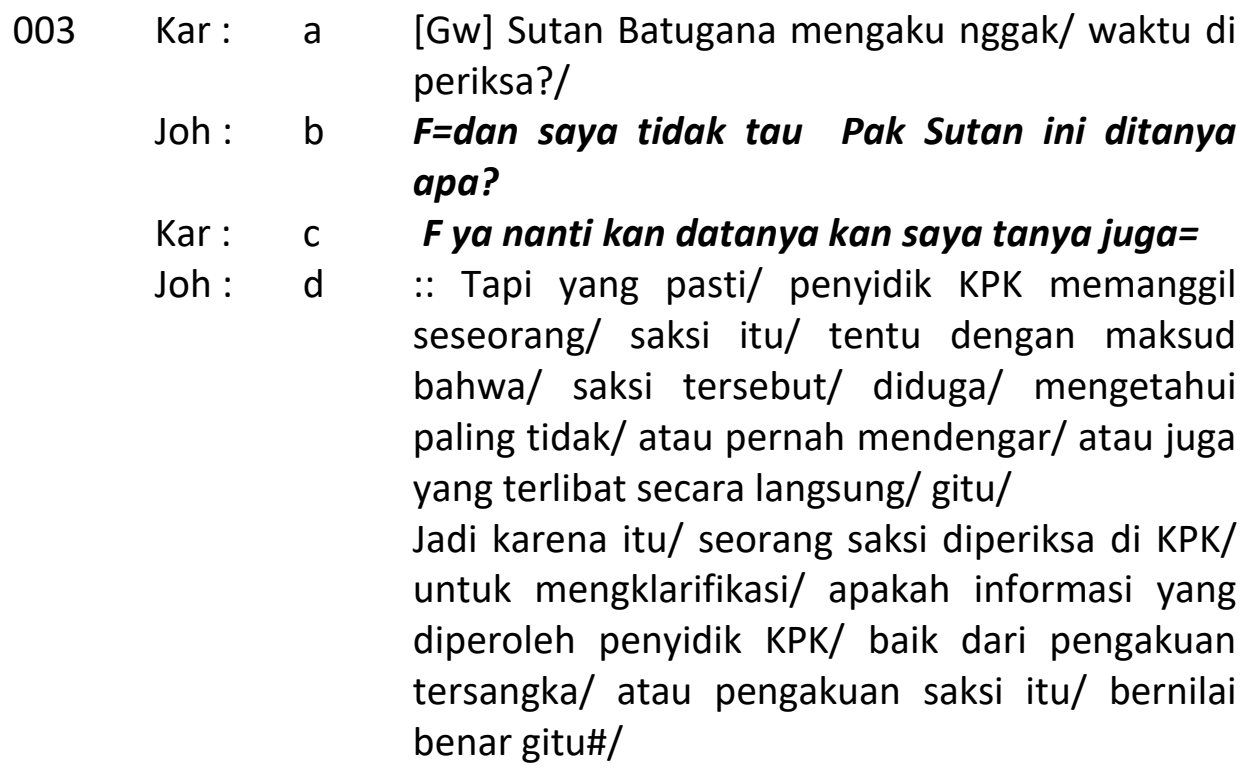

(017/TW-kl/ Cur/K2/Joh* Kar)

Berikut adalah beberapa hasil analisis jenis jeda, gilir wicara dan tumpang wicara. Dalam hasil penelitian, terdapat beberapa jenis jeda berdasarkan posisi dan durasi.

\section{Jeda dalam Wacana Debat ILC}

Berdasarkan penganalisisan data ditemukan 11 jenis jeda. Jenis jeda tersebut dapat dibagi menjadi jeda berdasarkan durasi dan jeda berdasarkan posisi. Jeda berdasarkan durasi ada tiga jenis, yaitu jeda panjang, jeda pendek, dan jeda selaan. Sementara itu, jeda berdasarkan posisi ada delapan, yaitu di awal tuturan, sebelum kata pertama, di awal tuturan, setelah kata pertama, di akhir kalimat sebagai penanda intonasi final ( . / ? / !), di akhir kalimat, sebelum kalimat baru dalam satu tuturan, di sekitar Konjungsi, pada bagian tuturan yang 
terputus-putus, sebelum dan sesudah kata sapaan / nama orang, dan di antara rincian / kata-kata bersinonim. Jenis-jenis jeda ini terdapat dalam wacana debat ILC, sehingga jenis-jenis jeda pada wacana yang lain memiliki kemungkinan berbeda.

Dalam penelitian ini, temuan jenis-jenis jeda didasarkan pada kesenyapan saat seseorang berbicara dan mengambil nafas. Pada umumnya orang senyap sebentar, entah untuk bernafas entah untuk keperluan yang lain. Pada waktu berbicara, senyap untuk mengambil nafas sebenarnya tidak banyak hanya sekitar 5\% (Aicthison 1998: 238). Senyapan yang lebih umum terjadi adalah pada waktu orang ragu-ragu (hesitation). Kecuali ujaran tersebut telah merupakan klise hafalan, atau ujaran itu telah dipersiapkan dengan baik sebelumnya, umunya 30$50 \%$ ujaran ditandai oleh senyapan.

Sesuai dengan yang disampaikan oleh Aicthison, senyapan dalam berbicara ditemukan dalam penelitian jeda pada wacana debat ILC. Pengujaran yang ideal terwujud dalam suatu bentuk ujaran yang lancar, sejak ujaran itu dimulai sampai ujaran itu selesai. Kata-katanya terangkai dengan rapi, diujarkan dalam suatu urutan yang tak terputus, dam kalaupun ada senyapan, senyapan itu terjadi pada konstituen-konstituen yang memang memungkinkan untuk disenyapi. Intonasinya pun merupakan suatu kesatuan dari awal sampai akhir. Akan tetapi, ujaran ideal seperti ini tidak selamanya dapat kita buat. Tidak semua orang dapat berbicara selancar ini untuk semua topic pembicaraan. Pada umumnya orang berbicara sambil berpikir sehingga makin sulit topic yang dibicarakan makin besar jumlah senyapan yang muncul.

Akan tetapi, dalam banyak hal, penutur sering senyap waktu berbicara. Ada berbagai alasan mengapa penutur senyap. Pertama, orang senyap karena penutur telah terlanjur mulai dengan ujarannya, tetapi sebenarnya penutur belum siap untuk seluruh kalimat itu. Karena itu, penutur senyap sejenak untuk mencari kata atau kata-kata untuk melanjutkan ujarannya. Kedua, bisa juga kesenyapan seperti ini terjadi karena penutur lupa kata-kata yang penutur 208 | ISSN: 22477-5150 http://journal.unesa.ac.id/index.php/jpi 
perlukan. Karena itu, penutur harus mencarinya untuk melanjutkan ujarannya. Kemungkinan ketiga adalah bahwa penutur harus sangat berhati-hati dalam memilih kata agar dampaknya pada pendengar atau public tidak, misalnya, menghebohkan. Tipe ketiga ini umunya terjadi pada pejabat public atau kaum politikus yang harus berhati-hati memilih kata-katanya.

\section{Gilir Wicara dalam Wacana Debat ILC}

Sesuai dengan fokus dan tujuan penelitian yang diajukan Berdasarkan penganalisisan data ditemukan dua hal utama dalam analisis gilir wicara, yaitu pasangan ujaran berdekatan dan mekanisme gilir wicara. Jenis pasangan ujaran berdekatan yang ditemukan dalam penelitian ini ada empat, yaitu ujaran pertanyaan-jawaban, ujaran menyilakan-penerimaan, ujaran keluhan-alasan, dan ujaran salam-salam. Sementara itu, ditemukan dua jenis mekanisme gilir wicara, yaitu turn giving dan turn getting. Ditemukan 3 jenis turn giving, yaitu menyilakan, menguasai, dan menciptakan. Sementara itu, turn getting dibagi menjadi empat jenis yaitu memperoleh, menyela, melanjutkan, dan merebut.

Adakalanya pula petutur tidak yakin kapan penutur yang sedang berbicara mengakhiri ujarannya dan memberikan giliran berbicara pada petutur. Akan tetapi, biasanya petutur menjadikan akhir sebuah kalimat sebagai indikasi bahwa giliran penutur berbicara telah usai. Pada saat petutur tidak mau menunggu mendapatkan gilirannya hingga penutur mengakhiri ujarannya, maka akan terjadi interupsi. Hal ini dapat dilihat pada contoh percakapan (3). Interupsi, yang ditandai dengan simbol "//", terjadi pada saat penutur A belum menyelesaikan ujarannya tetapi baru sampai pada kata "itu", petutur B sudah mengambil alih giliran berbicara dan berganti peran menjadi penutur selanjutnya yang diawali dengan partikel wacana berupa filled pauses "umm".

Pendapat yang dikemukakan oleh Cutler dan Pearson (dalam Sabat, 1991:161) serta fenomena seperti contoh di atas merupakan refleksi model 
mekanisme gilir wicara yang dikemukakan oleh Sacks, Schegloff, dan Jefferson (1974). Berdasarkan teori mereka, dapat dipahami bahwa melalui mekanisme gilir wicara dapat dikaji bagaimana struktur dan organisasi percakapan dilihat dari cara partisipan percakapan mengelola dan berbagi giliran dengan lawan bicaranya.

Selain itu, tujuan pendekatan mekanisme gilir wicara ini adalah untuk menemukan formula-formula, seperti siapa yang mendapatkan giliran untuk berbicara; aturan apa yang berlaku untuk mendapatkan giliran bicara, dan sinyal khusus apa yang muncul dalam percakapan sebagai pemarkah adanya giliran bicara.

\section{Tumpang Wicara dalam Wacana Debat ILC}

Berdasarkan penganalisisan data ditemukan tiga hal utama dalam analisis tumpang wicara, yaitu pengklasifikasian jenis berdasarkan panjang kata yang terlibat dalam gilir wicara dan jenis mekanisme tumpang wicara yang terjadi. Berdasarkan panjang kata yang terlibat dalam gilir wicara, maka gilir wicara dapat dibagi menjadi tumpang kata (jika terdapat 1-2 kata yang diucapkan bersamaan), tumpang frasa (jika terdapat 3-4 kata yang diucapkan bersamaan), dan tumpang klausa (jika terdapat lebih dari 4 kata yang diucapkan bersamaan). Sementara itu, tumpang wicara juga dapat diklasifikasikan berdasarkan mekanisme terjadinya, yaitu menyela, merebut dan mencuri. Kombinasi antara jumlah kata yang terucap bersamaan dan mekanisme tumpang wicara dapat menjadi sembilan kombinasi, yaitu tumpang kata menyela-mencuri merebut, tumpang frasa menyela-mencuri merebut, dan tumpang klausa menyelamencuri-merebut.

Berdasarkan hasil analisis yang telah dilakukan, tumpang kata lebih cenderung merupakan tumpang wicara berjenis menyela karena hanya bersinggungan pada 1-2 kata di akhir tuturan $n$ dan di awal tuturan $t$ tanpa adanya tuturan lanjutan. Sedangkan, tumpang frasa lebih cenderung merupakan 
tumpang wicara berjenis mencuri karena setelah 3-4 kata yang saling bersinggungan di akhir tuturan $n$ dan di awal tuturan $t$, dilanjutan dengan tuturan pendek dari $t$. Sementara itu, tumpang klausa lebih cenderung merupakan tumpang wicara berjenis merebut karena setelah lebih dari 4 kata yang saling bersinggungan di akhir tuturan $n$ dan di awal tuturan $t$, dilanjutan dengan tuturan panjang dari $t$.

Dalam suatu percakapan, setiap pertanyaan pasti ada jawaban. Walaupun pertanyaan itu merupakan pertanyaan retorik, pada dasarnya pertanyaan retorik pun mempunyai jawaban, tetapi jawabannya sudah dapat ditebak. Setiap kita berkomunikasi, antara penutur dan mitra tutur mempunyai kesempatan yang sama untuk memenuhi gilirannya yaitu terjadinya tumpang wicara. Hal ini akan menjadi sebuah permasalahan dalam sebuah percakapan dan akan menimbulkan suasana yang kurang mengenakkan untuk menjalin sebuah komunikasi.

Sebagian besar percakapan, sedikit banyaknya pasti terdapat jeda. Baik jeda yang berlangsung sebentar maupun jeda yang berlangsung lama. Hal ini sering terjadi pada sebuah percakapan yang melibatkan dua orang ataupun lebih karena dalam pengambilan giliran dan hanya ada satu orang yang berbicara saat itu.

Fenomena tumpang wicara kalimat dalam penelitian ini di analisis berdasarkan kategori tumpang wicara yang di bagi atas tiga bagian yakni, tumpang wicara transitional onset, tumpang wicara recogtional onset dan tumpang wicara progressional onset. Pembahasan ini termasuk dalam ruang lingkup analisis konversasi (conversation analysis). Dalam fenomena bahasa yang di amati terdapat beberapa fenomena yang terjadi di antaranya: pasangan sepadan (Levinson, 1983.p.303), interupsi (Jefferson, 1983), jeda (Yule, 1993), gilir wicara (Sacks, at al, 1974), tumpang wicara (Jefferson, 1983). 


\section{SIMPULAN}

Sesuai dengan fokus dan tujuan penelitian yang diajukan pada bab terdahulu, serta melalui penganalisisan data, penelitian ini dapat ditarik simpulan berkaitan dengan struktur konversasi wacana debat dalam ILC sebagai berikut.

Pertama, jeda dalam ILC terbagi dpaat dianalisis berdasarkan dua katagori, yang pertama berdasarkan durasi, dan yang kedua berdasarkan posisi. Jeda berdasarkan durasi dapat dibagi menjadi tiga macam yaitu jeda panjang pendek, dan jeda selaan. Acuan untuk menentukan standar jeda panjang, pendek, dan selaan dalam peneitian ini adalah dalam hal kemungkinan jeda dapat disela atau tidak, tapi dalam penelitian ini ditemukan standar waktu jeda sesuai dengan data yang muncul. Jeda pendek adalah jeda dengan durasi waktu kurang dari 1s. Jeda panjang merupakan jeda dengan durasi waktu lebih dari satu detik. Sementara itu, jeda selaan adalah jeda dengan durasi $0 \mathrm{~s}$ atau disebut pula kondisi tanpa jeda.

Jeda berdasarkan posisi dapat dibagi menjadi tiga katageori besar, yaitu (1) jeda di awal tuturan, (2) jeda di akhir tuturan, dan (3) jeda di tengah tuturan. Jeda di awal tuturan masih dapat dibagi lagi menjadi jeda di awal tuturan sebelum kata pertama dan jeda di awal tuturan setelah kata pertama. Jeda di akhir tuturan dapat dibagi lagi menjadi jeda di akhir kalimat sebagai penanda intonasi final dan jeda di akhir kalimat sebelum kalimat baru dalam satu tuturan. Sementara itu, jeda di tengah tuturan dapat dibagi menjadi jeda di sekitar konjungsi, jeda pada bagian tuturan yang terputus-putus, jeda sebelum dan setelah kata sapaan atau nama orang, dan jeda di antara rincian atau kata-kata bersinonim.

Kedua, gilir wicara dalam penelitian ini dapat dibagi menjadi dua katagori besar yaitu pasangan ujaran berdekatan dan mekanisme gilir wicara. Pasangan ujaran berdekatan yang muncul dalam penelitian ini adalah ujaran pertanyaanjawaban, ujaran menyilakan-penerimaan, ujaran keluhan-alasan, ujaran salamsalam. Sementara itu, mekanisme gilir wicara dalam penelitian ini dibagi menjadi 
dua katagori utama yaitu (1) memberikan (turn giving) yang di dalamnya terdapat mekanisme menyilakan, menguasai, menciptakan, dan mengawali; (2) menerima (turn getting ) yang di dalamnya terdapat mekanisme memperoleh, menyela, melanjutkan, merebut, dan interupsi.

Ketiga, tumpang wicara dalam penelitian ini dapat dibagi menjadi tiga katagori besar yaitu (1) tumpang kata, (2) tumpang frasa, dan (3) dan tumpang klausa. Tumpang kata dalam penelitian ini cenderung terjadi pada kondisi menyela. Tumpang Frasa dalam penelitian ini cenderung terjadi pada kondisi mencuri. Sementara itu, tumpang klausa dalam penelitian ini cenderung terjadi pada kondisi merebut.

\section{DAFTAR RUJUKAN}

Bogdan, R.C. dan Biklen, S.K.1990. Qualitative Research for Education (An Introduction to Theories and Methods). New York: Pearson Education Group.

Brown, Gillian dan George Yule, 1996. Analisis Wacana. Terjemahan oleh I Soetikno, Jakarta: PT Gramedia Pustaka Utama.

Clyne, Michael. 1994. Cultural Variation in the Interrelation of Speech Acts and Turn-Taking dalam Language Contact and Language Conflict. Amsterdam/Philadelphia: John Benjamins Publishing Company.

Cummings, Louis. 2007. Pragmatik (Sebuah Perspektif Multidisipliner). Terjemahan oleh Abdul Syukur Ibrahim. Yogyakarta: Pustaka Pelajar.

Khotim, Edan Handayani, Y. 2001. Jurnal Analisis Sosial. Bandung: Yayasan Akatiga.

Duijah, N, 2005. Wacana (Jurnal Ilmu Pengetahuan Budaya "Naskah Tradisi Lisan dan Sejarah"). Jakarta: Universitas Indonesia.

Eriyanto. 2009. Analisis Wacana (Pengantar Analisis Teks Media). Yogyakarta: LKIS Printing Cemerlang. 
Firth, J. R. 1957. Papaers in Linguistics. London: Oxford University Press.

Goffman, E. 1967. Replies and Responses (Language and Society). Garden City: Douleday.

Hasan, Ruqoyahdan Halliday. 1992. Bahasa, Konteks, dan Teks (Aspek-aspek Bahasa dalam Pandangan Semiotik Sosial). Yogyakarta: Gadjah Mada University Press.

Hayon, Josep. 2007. Membaca dan Menulis Wacana (Petunjuk Praktis bagi Mahasiswa). Jakarta: Grasindo.

Ibrahim, A.S. 1993. Kajian Tindak Tutur. Surabaya: Usaha Nasional.

Ibrahim, A.S. 1996. Bentuk Direktif Bahasa Indonesia: Kajian Etnografi Komunikasi. Disertasi tidak diterbitkan. Surabaya: Universitas Airlangga.

Jefferson, Gail (1983) Another Failed Hypothesis: Pitch/Loudness as Relevant to Tumpang wicara Resolution. Tilburg Papers in Language and Literature, No. 38, 1-24. Tilburg: Tilburg University.

Leech, Geoffrey. 2001. Prinsip-prinsip Pragmatik. Jakarta: Universitas Indonesia.

Laver J. 1975. Comunicative Functions of Phatic Communion (The Organization of Behavior in Face to Face Communication). The Hague: Mouton.

Levinson, Stephen C. 1983. Pragmatics. Great Britain: Cambridge University Press.

Mey, Jacob L.Pragmatics: An Introduction (Australia, Blackwell Publishing, 2001), h.137

Milis, Matthew B. Dan Huberman, A. Michael. 1992. Analisis data kualitatif. Terjemahan Tjetjep Rohendi Rohidi. Bandung: PT. Remaja Rosdakarya.

Moleong, L.J. 1995. Metodologi Penelitian Kualitatif. Bandung: Remaja Rosdakarya.

Moleong, L.J. 2006. Metodologi Penelitian Kualitatif. Bandung: Remaja Rosdakarya.

Morrisan \& Andy Corry Wardhany. 2009. Teori Komunikasi, Tentang komunikator, pesan, konversasi, dan hubungan. Jakarta:Ghalia Indonesia. 
Dewi Puspa Arum, Struktur Konversi Wacana...(hal. 188 - 215)

Nadar, F.X. 2009. Pragmatik dan Penelitian Pragmatik. Yogyakarta: Graha Ilmu.

Purwo, K. 1993. PELBA 6 (Pertemuan Linguistik Lembaga Bahasa Atma Jaya). Jakarta: Lembaga Bahasa UNIKA Atma Jaya .

Purwo, K. 2000. Kajian Serba Linguistik (untuk Anton Moeliono). Jakarta: PT. BPK Gunung Mulia.

Richard, J.C. dan Schimidt R. W. 1983. Language and Communication . London and New York: Longman.

Schffrin, Deborah. 2007. Ancangan Kajuan Wacana. Terjemahan oleh Abdul Syukur Ibrahim. Yogyakarta: Pustaka Pelajar.

Titscher, dkk. 2009. Metode Analisis Teks dan Wacana. Terjemahan oleh Abdul Syukur Ibrahim. Yogyakarta: Pustaka Pelajar.

Yule, George. 2006. Pragmatik. Terjemahan oleh Indah Fajar Wahyuni. Yogyakarta: Pustaka Pelajar. 